\title{
Oxidation of alcohols to carbonyl compounds with molecular iodine in the presence of potassium tert-butoxide
}

\author{
Qun-Li Luo, Wen-Hui Nan, Yu Li, and Xiang Chen \\ Key Laboratory of Applied Chemistry of Chongqing Municipality, College of Chemistry and \\ Chemical Engineering, Southwest University, Chongqing 400715, China \\ E-mail:qlluo@swu.edu.cn
}

DOI: http://dx.doi.org/10.3998/ark.5550190.0015.500

\begin{abstract}
An efficient protocol for the oxidation of alcohols to carbonyl compounds with molecular iodine and potassium tert-butoxide is described. Various primary and secondary alcohols were converted to the corresponding aldehydes and ketones in high yields. The oxidation of 2phenylethanol produced an "abnormal" acetalic ketone. The readily availability of starting materials, convenient synthetic procedure, operational simplicity, mild reaction conditions, and high yields makes this protocol a competitive alternative in the synthesis of ynones and ketones as well as aryl aldehydes.
\end{abstract}

Keywords: Molecular iodine, alcohol oxidation, aldehyde, ynone

\section{Introduction}

Carbonyl compounds are valuable intermediates in the manufacture of agrochemicals, dyes, pharmaceuticals, and fine chemicals. ${ }^{1}$ Preparation of carbonyl compounds can be achieved through the oxidation of alcohols using a variety of oxidants. ${ }^{2}$ Halogens and related reagents have been attractive oxidants because they are widely available and fairly cheap. As an oxidant of group VIIa, molecular iodine is distinguished by its low toxicity, operational simplicity and mild oxidation strength compared to other halogens. ${ }^{3,4}$ As an environmentally benign oxidizing agent, molecular iodine has been used in various organic reactions. ${ }^{5-9}$ It is known that secondary alcohols are readily converted into ketones, while primary alcohols can be first oxidized into the aldehydes and further into the carboxylic acids or their derivatives. Thus, the oxidation of primary alcohols to the corresponding carbonyl compounds is not so easily controlled as that of secondary alcohols. Accordingly, primary alcohols can be facilely oxidized to esters, ${ }^{10}$ amides, ${ }^{11}$ nitriles, ${ }^{12}$ and azolines ${ }^{13}$ by molecular iodine in basic solution, while there are only a few examples that involve oxidizing primary alcohols to aldehydes with molecular iodine. ${ }^{14-18}$ Among them, Itoh and co-workers developed an iodine oxidation involving photoirradiation at 
room temperature, ${ }^{14}$ Miller and co-workers reported iodine oxidations in the presence of 2,2,6,6,tetramethyl-1-piperdinyloxyl (TEMPO), ${ }^{15}$ Konwar et al expanded the complex oxidation system of DMSO/ $\mathrm{N}_{2} \mathrm{H}_{4} \cdot \mathrm{H}_{2} \mathrm{O} / \mathrm{I}_{2} / \mathrm{H}_{2} \mathrm{O} / \mathrm{CH}_{3} \mathrm{CN}$ under refluxing conditions and that of $\mathrm{KI} / \mathrm{I}_{2} / \mathrm{K}_{2} \mathrm{CO}_{3} / \mathrm{H}_{2} \mathrm{O}$ at $90{ }^{\circ} \mathrm{C},{ }^{16,17}$ and Lee et al performed the oxidation of benzyl alcohols with iodine and $\mathrm{Li}_{2} \mathrm{CO}_{3}$ in an ionic liquid at $60{ }^{\circ} \mathrm{C}$. ${ }^{18}$ These results demonstrate that molecular iodine struggles to oxidize alcohols into aldehydes without the help of heating, photoirradiation or co-activators because of its intrinsically low oxidizing strength.

The values of standard electrode potentials suggest that the hypohalogenite is a stronger oxidant than the corresponding elemental halogen under standard conditions. ${ }^{19}$ Thus, the oxidizing strength of molecular iodine can be promoted after it is transformed to hypoiodite. As an oxidant with useful synthetic utility, tert-butyl hypoiodite can be in situ generated from the very simple protocol, ${ }^{20}$ i.e. the reaction of molecular iodine with potassium tert-butoxide $(t$ BuOK). ${ }^{21}$ The oxidation of secondary alcohols to ketones by tert-butyl hypoiodite, in situ

generated from $t$-BuOK and molecular iodine, has been reported for half a century, ${ }^{22}$ but there are no related studies into the oxidation of primary alcohols to aldehydes, although it is interesting but challenging because an aldehyde is theoretically inclined to undergo the Tishchenko reaction ${ }^{23}$ in the presence of an alkoxide, and hence, oxidation products were more likely to stay in the stage of esters rather than that of aldehydes under such conditions. In addition, the oxidation of propargyl alcohols to ynones with molecular iodine has been unreported. Following our research on the reactions promoted by molecular iodine, ${ }^{24}$ we fully investigated the oxidation of alcohols to carbonyl compounds with molecular iodine in the presence of $t$-BuOK, and disclosed that oxidizing alcohols to aldehydes and ynones could be achieved with the combination of molecular iodine and $t$-BuOK. This simple protocol has been elaborated to achieve the conversion of 1-arylmethanols to aryl aldehydes, avoiding further transformation of the generated aldehydes to esters in the presence of alkoxides. Our investigations exemplify the versatility of molecular iodine in organic reactions and enrich the realm of halogen chemistry.

\section{Results and Discussion}

Initially, 1-naphthylmethanol, a primary alcohol that is easily converted to 1-naphthaldehyde, was chosen as the substrate in the model reaction. The investigation began with solvent screening experiments at a relatively low temperature (Table 1, Entries 1-5). Despite the moderate yields, the transformations did work at $-15{ }^{\circ} \mathrm{C}$ in various aprotic solvents, except for acetonitrile. A possible explanation was that acetonitrile was incompatible with the reaction system because of the relatively high acidity of its $\alpha$-hydrogen. When the temperature was increased to $10{ }^{\circ} \mathrm{C}$, the yields grew by nearly $20 \%$ (Entries 3-5 vs $6 \& 7$ ), and no over-oxidation products were detected by thin layer chromatography (TLC). Thus, the base screening experiments were performed at $10{ }^{\circ} \mathrm{C}$. Among the tested solvents, dichloromethane (DCM) gave a sound performance (Entry 7). DCM is cheap, able to dissolve most organic chemicals, 
relatively easy to dry, and not particularly hygroscopic, and was therefore the solvent of choice for the next investigations. The results of the base screening experiments (Entries 9-15) showed that the conversions did not work with most other tested bases except carbonates, with which single digit yields were obtained (Entries $12 \& 13$ ). In contrast, $t$-BuOK was significantly superior (Entries 9-15 vs 7). When the amount of iodine was increased to double the stoichiometry required, an excellent yield was obtained in a short time (Entry 8), which showed that the conversion could be accelerated with excess oxidant.

Table 1. Reaction condition screening for the oxidation of 1-naphthylmethanol by molecular iodine $^{a}$

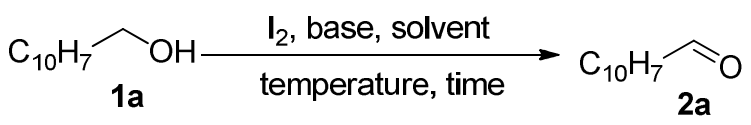

\begin{tabular}{|c|c|c|c|c|c|c|c|c|c|}
\hline Entry & Base & Solvent & Temperature & Yield $^{b}$ & Entry & Base & Solvent & Temperature & Yield $^{b}$ \\
\hline 1 & $t$-BuOK & $\mathrm{CH}_{3} \mathrm{CN}$ & $-15^{\circ} \mathrm{C}$ & 0 & 9 & $\mathrm{Et}_{3} \mathrm{~N}$ & $\mathrm{CH}_{2} \mathrm{Cl}_{2}$ & $10^{\circ} \mathrm{C}$ & 0 \\
\hline 2 & $t$-BuOK & $\mathrm{DMF}$ & $-15^{\circ} \mathrm{C}$ & $26 \%$ & 10 & DIPEA & $\mathrm{CH}_{2} \mathrm{Cl}_{2}$ & $10^{\circ} \mathrm{C}$ & 0 \\
\hline 3 & $t$-BuOK & DMA & $-15^{\circ} \mathrm{C}$ & $46 \%$ & 11 & DBU & $\mathrm{CH}_{2} \mathrm{Cl}_{2}$ & $10^{\circ} \mathrm{C}$ & 0 \\
\hline 4 & $t$-BuOK & THF & $-15^{\circ} \mathrm{C}$ & $45 \%$ & 12 & $\mathrm{~K}_{2} \mathrm{CO}_{3}$ & $\mathrm{CH}_{2} \mathrm{Cl}_{2}$ & $10^{\circ} \mathrm{C}$ & $5 \%$ \\
\hline 5 & $t$-BuOK & Toluene & $-15^{\circ} \mathrm{C}$ & $48 \%$ & 13 & $\mathrm{Na}_{2} \mathrm{CO}_{3}$ & $\mathrm{CH}_{2} \mathrm{Cl}_{2}$ & $10^{\circ} \mathrm{C}$ & $7 \%$ \\
\hline 6 & $t$-BuOK & Toluene & $10^{\circ} \mathrm{C}$ & $64 \%$ & 14 & $\mathrm{~K}_{3} \mathrm{PO}_{4}$ & $\mathrm{CH}_{2} \mathrm{Cl}_{2}$ & $10^{\circ} \mathrm{C}$ & 0 \\
\hline 7 & $t$-BuOK & $\mathrm{CH}_{2} \mathrm{Cl}_{2}$ & $10^{\circ} \mathrm{C}$ & $77 \%$ & 15 & $\mathrm{KF}$ & $\mathrm{CH}_{2} \mathrm{Cl}_{2}$ & $10^{\circ} \mathrm{C}$ & 0 \\
\hline $8^{c}$ & $t$-BuOK & $\mathrm{CH}_{2} \mathrm{Cl}_{2}$ & $10^{\circ} \mathrm{C}$ & $90 \%$ & & & & & \\
\hline
\end{tabular}

${ }^{a}$ Reaction conditions: 1-naphthylmethanol (1 mmol), iodine $(1.2 \mathrm{mmol})$, base $(2.5 \mathrm{mmol})$, and solvent ( $5 \mathrm{~mL}$ ), $24 \mathrm{~h}$ unless noted otherwise. $\mathrm{C}_{10} \mathrm{H}_{7}=1$-naphthyl.

${ }^{b}$ The product was isolated by chromatographic purification on silica column.

${ }^{c}$ 1-naphthylmethanol (1 mmol), iodine $(2 \mathrm{mmol})$, base $(4.2 \mathrm{mmol})$, and DCM $(5 \mathrm{~mL}), 1.5 \mathrm{~h}$.

To further assess the effect of reaction temperature on the yield, the oxidizations of another substrate, 4-methoxybenzyl alcohol, to 4-methoxybenzaldehyde from $-40{ }^{\circ} \mathrm{C}$ to $40{ }^{\circ} \mathrm{C}$ were examined. As shown in Figure 1, the highest yield $(91 \%)$ was obtained at $10{ }^{\circ} \mathrm{C}$. When the temperature was lower than $10{ }^{\circ} \mathrm{C}$, the reaction was slow, while at higher temperatures, side reactions did increase. Thus, $10{ }^{\circ} \mathrm{C}$ was further confirmed as the optimal temperature for the oxidization of alcohols to carbonyl compounds.

Under the optimized conditions, the oxidizations of various alcohols to carbonyl compounds were investigated. The results, summarized in Table 2 , show that a wide range of alcohols, both primary and secondary, were smoothly converted to carbonyl compounds giving the expected aldehyde or ketone in mostly good to excellent yields. Several $\alpha$-aryl primary and secondary alcohols gave yields higher than 95\% (Entries 2, 6, 12, 15). In general, the substrates containing electron-donating substituted aryl groups were more active than those containing electron- 
withdrawing groups (Entries 3 vs 5-10; 13 vs 14). For sluggish substrates, increasing the amounts of iodine and $t$-BuOK produced better results (Entries 6-10). Among the tested substrates, 4-nitrobenzyl alcohol was the least active, with the yield being improved to $60 \%$ with the use of a fivefold stoichiometric amount of iodine and a four fold stoichiometric amount of $t$ $\mathrm{BuOK}$ (Entries 9 vs 10). For the active substrates, slightly decreasing the amount of $t$-BuOK was favored (Entries 1 vs 2, 12). For those oxidations in which the desired aryl aldehydes were inclined to undergo the Tishchenko reaction, decreasing the reaction temperature along with increased amounts of iodine and $t$-BuOK was the better choice (Entries $7 \& 8$ ). Moreover, cinnamyl alcohol (1i) was exclusively transformed into cinnamaldehyde (2i) in $82 \%$ yield in a short time, and neither iodinated nor oxidized products of the carbon-carbon double bond were identified, ${ }^{25}$ which implies that the $\mathrm{C}=\mathrm{C}$ bond of allyl alcohols is not iodinated or oxidized by the current protocol.

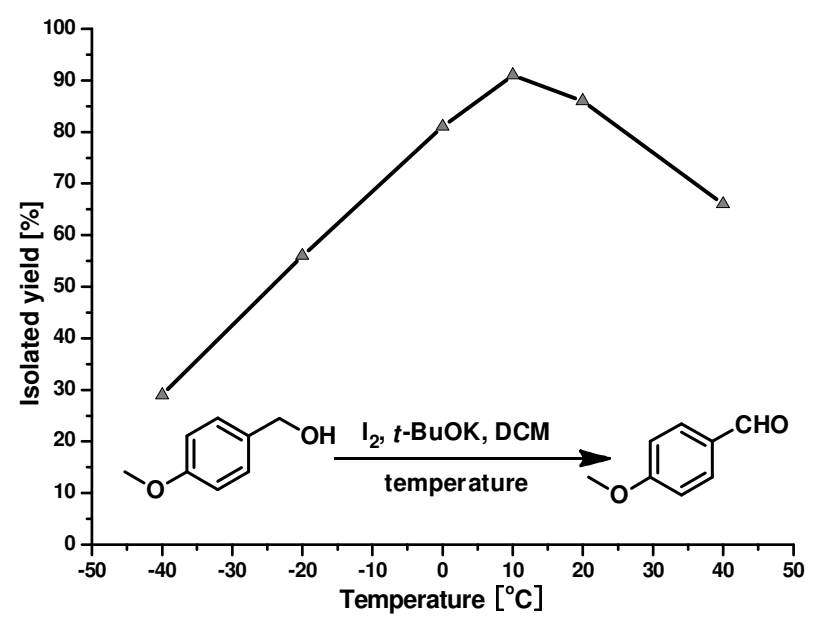

Figure 1. Influence of temperature on the oxidation of 4-methoxybenzyl alcohol by molecular iodine. ${ }^{\text {a }}$ Reaction conditions: 4-methoxybenzyl alcohol $(1 \mathrm{mmol})$, iodine $(2 \mathrm{mmol}), t$-BuOK $(4.2$ $\mathrm{mmol})$, and DCM $(5 \mathrm{~mL})$ at the indicated temperature. For the temperature at or below $0{ }^{\circ} \mathrm{C}$, the reaction time was $10 \mathrm{~h}$, while for that above $0{ }^{\circ} \mathrm{C}$, the reaction time was $6.5 \mathrm{~h}$. Yield of the isolated product after silica gel chromatography.

To our delight, a variety of substituted propargylic alcohols derived from aliphatic or aromatic alkynes were compatible with the reaction conditions, and clean ynones were obtained in good to excellent yields (Entries 13-17). The most common methods for the preparation of ynones involve the metal-catalyzed couplings of acyl halides and terminal alkynes (or alkynyl metal) as well as the Pd-catalyzed acyl or carbonylative Sonogashira reactions. ${ }^{26-28}$ In addition, there are a few metal-free methodologies reporting the oxidation of propargylic alcohols with different oxidation systems. ${ }^{29}$ However, the use of molecular iodine is unprecedented. Thus, the present protocol provides a competitive alternative method for the synthesis of ynones because of its efficiency and avoiding both metals and peroxides. 
Table 2. Substrate scope of the oxidation of alcohols to carbonyl compounds by iodine ${ }^{a}$

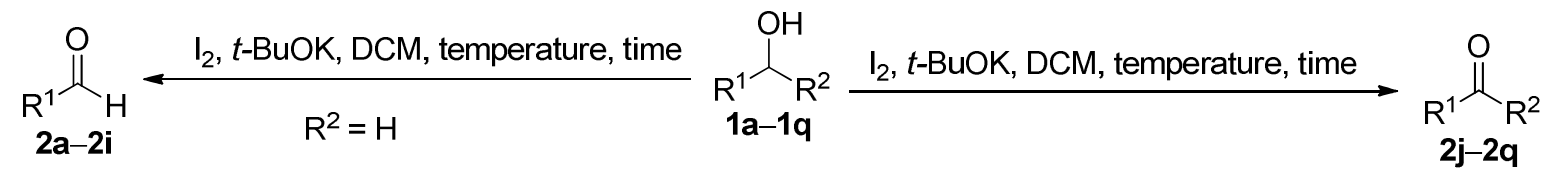

\begin{tabular}{|c|c|c|c|c|c|c|c|}
\hline Entry & $\mathrm{R}^{1}$ & $\mathrm{R}^{2}$ & Alcohol 1 & Temperature & Time & Product 2 & Yield $^{b}$ \\
\hline 1 & 1-naphthyl & $\mathrm{H}$ & $1 \mathbf{a}$ & $10{ }^{\circ} \mathrm{C}$ & $1.5 \mathrm{~h}$ & $2 \mathbf{a}$ & $90 \%$ \\
\hline $2^{c}$ & 1-naphthyl & $\mathrm{H}$ & $1 a$ & $10{ }^{\circ} \mathrm{C}$ & $1.5 \mathrm{~h}$ & $2 \mathbf{a}$ & $>99 \%{ }^{f}$ \\
\hline 3 & $p-\mathrm{CH}_{3} \mathrm{OC}_{6} \mathrm{H}_{4-}$ & $\mathrm{H}$ & $1 b$ & $10{ }^{\circ} \mathrm{C}$ & $6.5 \mathrm{~h}$ & $2 b$ & $91 \%$ \\
\hline 4 & $p-\mathrm{CH}_{3} \mathrm{C}_{6} \mathrm{H}_{4}-$ & $\mathrm{H}$ & 1c & $10{ }^{\circ} \mathrm{C}$ & $7.5 \mathrm{~h}$ & $2 c$ & $83 \%$ \\
\hline 5 & $m-\mathrm{BrC}_{6} \mathrm{H}_{4}-$ & $\mathrm{H}$ & 1d & $10{ }^{\circ} \mathrm{C}$ & $8 \mathrm{~h}$ & 2d & $85 \%$ \\
\hline $6^{d}$ & $o-\mathrm{BrC}_{6} \mathrm{H}_{4-}$ & $\mathrm{H}$ & $1 \mathrm{e}$ & $10{ }^{\circ} \mathrm{C}$ & $5 \mathrm{~h}$ & $2 e$ & $>99 \%{ }^{f}$ \\
\hline $7^{d}$ & $p-\mathrm{ClC}_{6} \mathrm{H}_{4}-$ & $\mathrm{H}$ & 1f & $-20{ }^{\circ} \mathrm{C}$ & $2.5 \mathrm{~h}$ & $2 f$ & $76 \%$ \\
\hline $8^{e}$ & $o-\mathrm{ClC}_{6} \mathrm{H}_{4}-$ & $\mathrm{H}$ & $1 g$ & $-20{ }^{\circ} \mathrm{C}$ & $8 \mathrm{~h}$ & $2 \mathrm{~g}$ & $85 \%$ \\
\hline 9 & $p-\mathrm{NO}_{2} \mathrm{C}_{6} \mathrm{H}_{4}-$ & $\mathrm{H}$ & $1 \mathrm{~h}$ & $10{ }^{\circ} \mathrm{C}$ & $17 \mathrm{~h}$ & $2 \mathrm{~h}$ & $15 \%$ \\
\hline $10^{e}$ & $p-\mathrm{NO}_{2} \mathrm{C}_{6} \mathrm{H}_{4}-$ & $\mathrm{H}$ & $1 \mathrm{~h}$ & $10{ }^{\circ} \mathrm{C}$ & $20 \mathrm{~h}$ & $2 h$ & $60 \%$ \\
\hline $11^{c}$ & $\mathrm{C}_{6} \mathrm{H}_{5} \mathrm{CH}=\mathrm{CH}-$ & $\mathrm{H}$ & $\mathbf{1 i}$ & $10{ }^{\circ} \mathrm{C}$ & $2 \mathrm{~h}$ & $2 \mathbf{i}$ & $82 \%$ \\
\hline $12^{c}$ & phenyl & phenyl & $\mathbf{1 j}$ & $10{ }^{\circ} \mathrm{C}$ & $1.5 \mathrm{~h}$ & $2 j$ & $>99 \%{ }^{f}$ \\
\hline 13 & 2-phenylethynyl & $p-\mathrm{CF}_{3} \mathrm{C}_{6} \mathrm{H}_{4-}$ & $1 \mathbf{k}$ & $10{ }^{\circ} \mathrm{C}$ & $5 \mathrm{~h}$ & $2 k$ & $85 \%$ \\
\hline $14^{d}$ & 2-phenylethynyl & $p-\mathrm{CH}_{3} \mathrm{OC}_{6} \mathrm{H}_{4-}^{-}$ & 11 & $10{ }^{\circ} \mathrm{C}$ & $6 \mathrm{~h}$ & 21 & $98 \%$ \\
\hline $15^{d}$ & 2-phenylethynyl & thiophen-2-yl & $1 \mathrm{~m}$ & $10{ }^{\circ} \mathrm{C}$ & $3 \mathrm{~h}$ & $2 \mathrm{~m}$ & $97 \%$ \\
\hline $16^{d}$ & 1-hexynyl & $p-\mathrm{CH}_{3} \mathrm{OC}_{6} \mathrm{H}_{4-}$ & 1n & $10{ }^{\circ} \mathrm{C}$ & $4 \mathrm{~h}$ & $2 n$ & $88 \%$ \\
\hline $17^{d}$ & 2-phenylethynyl & $\mathrm{C}_{6} \mathrm{H}_{5} \mathrm{CH}=\mathrm{CH}-$ & 10 & $10{ }^{\circ} \mathrm{C}$ & $2.5 \mathrm{~h}$ & 20 & $90 \%$ \\
\hline $18^{c}$ & phenyl & ethyl & $1 p$ & $10{ }^{\circ} \mathrm{C}$ & $3 \mathrm{~h}$ & $2 p$ & $60 \%^{g}$ \\
\hline $19^{d}$ & phenyl & ethyl & $1 p$ & $-20{ }^{\circ} \mathrm{C}$ & $4 \mathrm{~h}$ & $2 p$ & $81 \%$ \\
\hline $20^{e}$ & $-\mathrm{CH}_{2} \mathrm{CH}_{2} \mathrm{CH}$ & $\mathrm{H}_{2} \mathrm{CH}_{2} \mathrm{CH}_{2^{-}}$ & $1 q$ & -40 to $-15^{\circ} \mathrm{C}$ & $3.5 \mathrm{~h}$ & $2 q$ & $>99 \%{ }^{f}$ \\
\hline
\end{tabular}

${ }^{a}$ Reaction conditions: alcohol $(1 \mathrm{mmol})$, iodine $(2 \mathrm{mmol}), t$-BuOK $(4.2 \mathrm{mmol})$, and DCM (5 $\mathrm{mL}$ ) unless noted otherwise.

${ }^{b}$ Yield of the isolated product after silica gel chromatography unless stated otherwise.

${ }^{c}$ The reactions were performed with iodine $(2 \mathrm{mmol})$ and $t$-BuOK $(3 \mathrm{mmol})$.

${ }^{d}$ The reactions were performed with iodine $(3 \mathrm{mmol})$ and $t$-BuOK $(5 \mathrm{mmol})$.

${ }^{e}$ The reactions were performed with iodine $(5 \mathrm{mmol})$ and $t$ - $\mathrm{BuOK}(8 \mathrm{mmol})$.

${ }^{f}$ The yield was determined by ${ }^{1} \mathrm{H}$ NMR. The ${ }^{1} \mathrm{H}$ NMR spectra indicated that the starting alcohol was completely transformed and there were no detectable side products inside except of the desired carbonyl compound.

${ }^{g}$ A mixture containing 2-iodopropionophenone (2p'). The molar ratio of $\mathbf{2 p}$ to $\mathbf{2} \mathbf{p}$ ', determined by ${ }^{1} \mathrm{H}$ NMR, was approximately $1: 2$. 
Notably, the oxidation of a secondary alcohol containing $\beta$-sp $\mathrm{s}^{3}$ hydrogen atoms possibly suffered from the further $\alpha$-iodination of the desired ketone (Entry 18). Nevertheless, this could be avoided by decreasing the reaction temperature along with increased amounts of iodine and $t$ BuOK (Entries $19 \& 20$ ). This protocol can, however, not be applied to the preparation of aliphatic aldehydes, since active aldehydes are inclined to undergo the disproportionation reactions in strongly basic solutions, by pathways such as the Tishchenko reaction and the Cannizzaro reaction, whereas aliphatic aldehydes containing $\alpha$-hydrogen atom(s) tend to condense with each other in basic solutions. Consequently, when primary alcohols containing $\beta$ hydrogen atom(s) were employed under the present protocol, the main reactions were the disproportionation of the aldehydes generated in situ to the corresponding esters, i.e. the Tishchenko reaction (Scheme 1). Increasing the steric hindrance of the $\beta$-alkyl substituted primary alcohol (e.g., 1t) led to a small amount of the corresponding tert-butyl ester (2t'). Interestingly, under the present protocol, 2-phenylethanol (1u) generated an acetal, 2,2diphenethoxy-1-phenylethanone (2u), in an acceptable yield of $42 \%$. Better results were not achieved despite of several optimization experiments. Other analogs of $\mathbf{1} \mathbf{u}$ containing electrondonating or electron-withdrawing groups mainly gave oxidations similar to that of $\beta$-alkyl substituted primary alcohols, and yielded the corresponding esters (results not shown because of their similarity to $\mathbf{1 r}$ ).

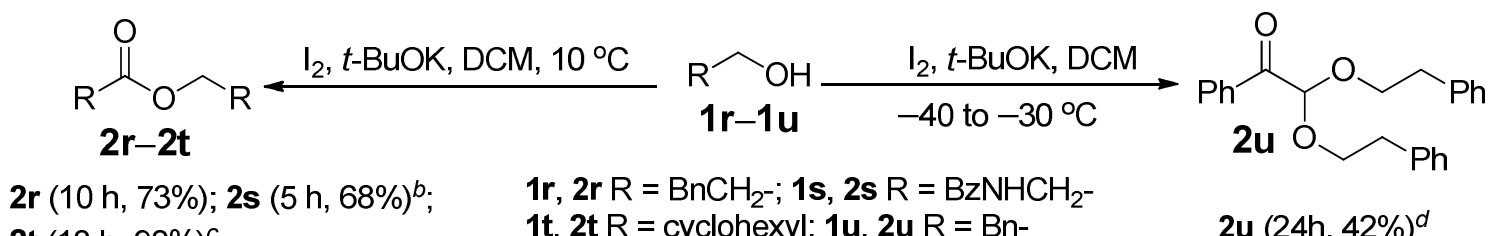

$2 t(18 \mathrm{~h}, 90 \%)^{c}$

1t, $2 \mathrm{t} \mathrm{R}=$ cyclohexyl; $1 \mathrm{u}, \mathbf{2 u} \mathrm{R}=\mathrm{Bn}-$

$2 \mathrm{u}(24 \mathrm{~h}, 42 \%)^{d}$

Scheme 1. Oxidation of primary alcohols containing $\beta$-hydrogen atom(s) with molecular iodine and $t$-BuOK. ${ }^{a}$

${ }^{a}$ Reaction conditions: alcohol $(1 \mathrm{mmol})$, iodine $(2 \mathrm{mmol}), t$-BuOK $(4.2 \mathrm{mmol})$, and DCM (5 mL) for the indicated time unless noted otherwise. Yield of the isolated product after silica gel chromatography.

${ }^{b}$ Alcohol (1 mmol), iodine (3 mmol), $t$-BuOK ( $\left.5 \mathrm{mmol}\right)$, and DCM $(5 \mathrm{~mL})$ were employed.

${ }^{c}$ A mixture containing tert-butyl cyclohexanecarboxylate (2t'). The molar ratio of $\mathbf{2 t}$ to $\mathbf{2 t}$ ' was about 78:22, which was determined by ${ }^{1} \mathrm{H}$ NMR.

${ }^{d}$ Alcohol $(1 \mathrm{mmol})$, iodine $(5 \mathrm{mmol}), t$-BuOK $(7.5 \mathrm{mmol})$, and DCM $(5 \mathrm{~mL})$ were employed.

Compared to the existing methods, the present protocol has several advantages. First, the reagents are widely available and much cheaper than those employed in many other oxidation systems. This reaction system does not require synthetic co-activators or special reagents. The required common reagents are only $t$-BuOK and $\mathrm{I}_{2}$, both commercially available in small amounts or in bulk and are quite cheap. Second, both reagents employed in this system and the 
corresponding side products $(t-\mathrm{BuOH}$ and $\mathrm{KI})$ have low toxicity and are environmentally benign. ${ }^{4,5}$ Neither transition metal-containing reagents nor peroxides are required, which is often problematic due to the disposal of metal waste, or due the risk of explosion from the latter. Third, this protocol permitted the reactions to be set up easily. Neither unstable reagents nor special equipment are needed as both $t$-BuOK and $\mathrm{I}_{2}$ are solid and stable towards air. Neither the reagent storage and transfer nor the reaction installation required special conditions or techniques.

\section{Conclusions}

The oxidation of various primary and secondary alcohols with molecular iodine proceeded smoothly in the presence of potassium tert-butoxide to afford the corresponding aldehydes and ketones in high yields at $10{ }^{\circ} \mathrm{C}$ or below. This simple protocol provides a competitive alternative method to synthesize ynones and ketones as well as aryl aldehydes from alcohols because of several practical features, including operational simplicity, mild reaction conditions, direct availability of starting materials, and high yields in a relatively short reaction time at easy-tocontrol reaction temperatures. Under the protocol, 2-phenylethanol yielded an unexpected product, 2,2-diphenethoxy-1-phenylethanone. These findings exemplify the versatility of molecular iodine in organic reactions and enriches the realm of halogen chemistry.

\section{Experimental Section}

General. Commercially available reagents were used as received. Solvents for reactions were dried with standard procedures and stored with Schlenk flasks over molecular sieves if not noted otherwise. All solvents for chromatographic separations were distilled before use. ${ }^{1} \mathrm{H}$ and ${ }^{13} \mathrm{C}$ NMR spectra were recorded on a Bruker av 300 spectrometer at $293 \mathrm{~K}$ and the chemical shifts $(\delta)$ were internally referenced by the residual solvent signals relative to tetramethylsilane $\left(\mathrm{CDCl}_{3}\right.$ at $7.26 \mathrm{ppm}$, and $\mathrm{CD}_{3} \mathrm{OD}$ at $3.31 \mathrm{ppm}$ for ${ }^{1} \mathrm{H} ; \mathrm{CDCl}_{3}$ at $77.00 \mathrm{ppm}$, and $\mathrm{CD}_{3} \mathrm{OD}$ at $49.00 \mathrm{ppm}$ for ${ }^{13} \mathrm{C}$ ). Data are reported as $(\mathrm{s}=$ singlet, $\mathrm{d}=$ doublet, $\mathrm{t}=$ triplet, $\mathrm{q}=$ quartet, $\mathrm{m}=$ multiplet, $\mathrm{b}=$ broad; coupling constant(s) in Hz; integration). High resolution mass spectra (HRMS) were obtained by electrospray ionization at the Department of Analytical Chemistry, Chengdu Institute of Biology, Chinese Academy of Sciences (CAS). All the known products were confirmed by comparison with spectroscopic analysis of the authentic samples (see Supplementary Material). The yields in Tables 1-2 and Scheme 1 refer to isolated yields of compounds (average of two runs) unless noted otherwise.

Starting alcohols $\mathbf{1 a}-\mathbf{1 j}, \mathbf{1 p}-\mathbf{1 r}, \mathbf{1 t}$ and $\mathbf{1 u}$, potassium tert-butoxide, and molecular iodine, are commercially available. The other starting alcohols $\mathbf{1 k}-\mathbf{1 0}$, and $\mathbf{1 s}$, were prepared, and the experimental details are described in Supplementary Material. 
General procedure for the oxidation of alcohols with molecular iodine and potassium tertbutoxide. (Tables 1 and 2, Scheme 1). In a typical run, a reaction flask (25 mL) was charged with an indicated amount of $\mathrm{I}_{2}$ (typically, $508 \mathrm{mg}, 2 \mathrm{mmol}$ ) and potassium tert-butoxide (typically, $470 \mathrm{mg}, 4.2 \mathrm{mmol}$ ). The mixture was suspended in $\mathrm{CH}_{2} \mathrm{Cl}_{2}(5 \mathrm{~mL})$ and stirred at $10{ }^{\circ} \mathrm{C}$ for $30 \mathrm{~min}$, then alcohol $(1 \mathrm{mmol})$ was added. The mixture was continually stirred at an indicated temperature (typically, at $10{ }^{\circ} \mathrm{C}$ ) until the consumption of the alcohol (monitoring with TLC, typically, for a few hours), then diluted with $\mathrm{CH}_{2} \mathrm{Cl}_{2}(10 \mathrm{~mL})$ and washed with saturated aqueous sodium thiosulfate $(10 \mathrm{~mL})$. The aqueous phase was extracted with $\mathrm{CH}_{2} \mathrm{Cl}_{2}$ (three portions of 10 $\mathrm{mL}$ each). The combined organic phase was washed with deionized water and saturated aqueous $\mathrm{NaCl}$, dried over anhydrous $\mathrm{Na}_{2} \mathrm{SO}_{4}$, and then filtered and concentrated. The crude product was purified by column chromatography (silica, hexane or hexane/EtOAc mixture as eluent). The yields are listed in Tables 1 and 2 as well as Scheme 1.

1-Naphthaldehyde (2a). ${ }^{30}$ A white amorphous solid (111 mg, 90\% yield). ${ }^{1} \mathrm{H}$ NMR $\left(\mathrm{CDCl}_{3}, 300\right.$ MHz): $\delta 10.36(\mathrm{~s}, 1 \mathrm{H}), 9.26(\mathrm{~d}, J 8.5 \mathrm{~Hz}, 1 \mathrm{H}), 8.05(\mathrm{~d}, J 8.2 \mathrm{~Hz}, 1 \mathrm{H}), 7.94(\mathrm{~d}, J 6.9 \mathrm{~Hz}, 1 \mathrm{H}), 7.89$ $(\mathrm{d}, J 8.2 \mathrm{~Hz}, 1 \mathrm{H}), 7.68(\mathrm{t}, J 7.2 \mathrm{~Hz}, 1 \mathrm{H}), 7.61-7.54(\mathrm{~m}, 2 \mathrm{H}) \cdot{ }^{13} \mathrm{C} \mathrm{NMR}\left(\mathrm{CDCl}_{3}, 75 \mathrm{MHz}\right): \delta$ $193.44,136.61,135.15,133.54,131.18,130.33,128.92,128.34,126.81,124.73$.

4-Methoxybenzaldehyde (2b). ${ }^{30}$ Colorless oil (> 99\% yield). The yield was determined by ${ }^{1} \mathrm{H}$ NMR. ${ }^{1} \mathrm{H}$ NMR $\left(\mathrm{CDCl}_{3}, 300 \mathrm{MHz}\right): \delta 9.87(\mathrm{~s}, 1 \mathrm{H}), 7.83(\mathrm{~d}, J 8.6 \mathrm{~Hz}, 2 \mathrm{H}), 6.99(\mathrm{~d}, J 8.7 \mathrm{~Hz}, 2 \mathrm{H})$, 3.88 (s, 3H). ${ }^{13} \mathrm{C} \mathrm{NMR}\left(\mathrm{CDCl}_{3}, 75 \mathrm{MHz}\right): \delta 190.85,164.54,131.95,129.84,114.24,55.54$.

4-Methylbenzaldehyde (2c). ${ }^{30}$ A colorless oil $(100 \mathrm{mg}, 83 \%$ yield $) .{ }^{1} \mathrm{H}$ NMR $\left(\mathrm{CDCl}_{3}, 300\right.$ $\mathrm{MHz}): \delta 9.96(\mathrm{~s}, 1 \mathrm{H}), 7.77(\mathrm{~d}, J 8.0 \mathrm{~Hz}, 2 \mathrm{H}), 7.31(\mathrm{~d}, J 7.9 \mathrm{~Hz}, 2 \mathrm{H}), 2.44(\mathrm{~s}, 3 \mathrm{H}) .{ }^{13} \mathrm{C}$ NMR $\left(\mathrm{CDCl}_{3}, 75 \mathrm{MHz}\right): \delta 192.04,145.55,134.12,129.83,129.68,21.87$.

3-Bromobenzaldehyde (2d). ${ }^{30}$ A light yellow oil (157 mg, 85\% yield). ${ }^{1} \mathrm{H}$ NMR $\left(\mathrm{CDCl}_{3}, 300\right.$ MHz): $\delta 9.95(\mathrm{~s}, 1 \mathrm{H}), 7.99(\mathrm{t}, J 1.6 \mathrm{~Hz}, 1 \mathrm{H}), 7.81(\mathrm{~d}, J 7.6 \mathrm{~Hz}, 1 \mathrm{H}), 7.70$ (ddd, $J 1.0 \mathrm{~Hz}, 1.8 \mathrm{~Hz}$, $7.9 \mathrm{~Hz}, 1 \mathrm{H}), 7.42(\mathrm{~d}, J 7.8 \mathrm{~Hz}, 1 \mathrm{H}) .{ }^{13} \mathrm{C} \mathrm{NMR}\left(\mathrm{CDCl}_{3}, 75 \mathrm{MHz}\right): \delta 190.64,137.79,137.14$, 132.12, 130.50, 128.28, 123.19 .

2-Bromobenzaldehyde (2e). ${ }^{30}$ A light yellow oil (>99\% yield). The yield was determined by ${ }^{1} \mathrm{H}$ NMR from the extraction of the reaction mixture. ${ }^{1} \mathrm{H} \mathrm{NMR}\left(\mathrm{CDCl}_{3}, 300 \mathrm{MHz}\right): \delta 10.35(\mathrm{~s}, 1 \mathrm{H})$, 7.93-7.86 (m, 1H), 7.67-7.60 (m, 1H), 7.48-7.38 (m, 2H). ${ }^{13} \mathrm{C} \mathrm{NMR}\left(\mathrm{CDCl}_{3}, 75 \mathrm{MHz}\right): \delta$ $191.80,135.28,133.82,133.40,129.78,127.85,127.06$.

4-Chlorobenzaldehyde (2f). ${ }^{30}$ A colorless oil $\left(107 \mathrm{mg}, 76 \%\right.$ yield). ${ }^{1} \mathrm{H}$ NMR $\left(\mathrm{CDCl}_{3}, 300\right.$ $\mathrm{MHz}): \delta 9.98(\mathrm{~s}, 1 \mathrm{H}), 7.82(\mathrm{~d}, J 8.4 \mathrm{~Hz}, 2 \mathrm{H}), 7.81(\mathrm{~d}, J 8.4 \mathrm{~Hz}, 2 \mathrm{H}) .{ }^{13} \mathrm{C} \mathrm{NMR}\left(\mathrm{CDCl}_{3}, 75 \mathrm{MHz}\right)$ : $\delta 190.71,140.69,134.51,130.72,129.24$.

2-Chlorobenzaldehyde (2g). ${ }^{30}$ A colorless oil (119.5 mg, 85\% yield). ${ }^{1} \mathrm{H} \mathrm{NMR}\left(\mathrm{CDCl}_{3}, 300\right.$ MHz): $\delta 10.43(\mathrm{~s}, 1 \mathrm{H}), 7.78(\mathrm{dd}, J 1.6 \mathrm{~Hz}, 7.7 \mathrm{~Hz}, 1 \mathrm{H}), 7.41(\mathrm{dt}, J 1.6 \mathrm{~Hz}, 7.6 \mathrm{~Hz}, 1 \mathrm{H})$, 7.44-7.39 (m, 1H), 7.35-7.224 (m, 2H). ${ }^{13} \mathrm{C} \mathrm{NMR}\left(\mathrm{CDCl}_{3}, 75 \mathrm{MHz}\right): \delta 189.25,137.51,134.83$, $132.05,130.26,128.97,126.98$.

4-Nitrobenzaldehyde (2h). ${ }^{30}$ A slightly yellowish solid $(91 \mathrm{mg}, 60 \%$ yield $) .{ }^{1} \mathrm{H} \mathrm{NMR}\left(\mathrm{CDCl}_{3}\right.$, $300 \mathrm{MHz}): \delta 10.16(\mathrm{~s}, 1 \mathrm{H}), 8.40(\mathrm{~d}, J 8.6 \mathrm{~Hz}, 2 \mathrm{H}), 8.08$ (d, $J 8.7 \mathrm{~Hz}, 2 \mathrm{H}) .{ }^{13} \mathrm{C} \mathrm{NMR}\left(\mathrm{CDCl}_{3}, 75\right.$ $\mathrm{MHz}): \delta 190.26,151.11,140.03,130.48,124.31$. 
Cinnamaldehyde (2i). ${ }^{31}$ A slightly yellowish oil (108.4 mg, 82\% yield). ${ }^{1} \mathrm{H}$ NMR $\left(\mathrm{CDCl}_{3}, 300\right.$ $\mathrm{MHz}): \delta 9.70(\mathrm{~d}, J 7.7 \mathrm{~Hz}, 1 \mathrm{H}), 7.59-7.48(\mathrm{~m}, 3 \mathrm{H}), 7.46-7.40(\mathrm{~m}, 3 \mathrm{H}), 6.71$ (dd, $J 7.7 \mathrm{~Hz}, 16.0$ $\mathrm{Hz}, 1 \mathrm{H}) .{ }^{13} \mathrm{C} \mathrm{NMR}\left(\mathrm{CDCl}_{3}, 75 \mathrm{MHz}\right): \delta 193.80,152.88,133.84,131.22,129.01,128.42,128.40$. Benzophenone (2j). ${ }^{30,31} \mathrm{~A}$ white amorphous solid (180 mg, 99\% yield). ${ }^{1} \mathrm{H} \mathrm{NMR}\left(\mathrm{CDCl}_{3}, 300\right.$ MHz): $\delta 7.80(\mathrm{~d}, J 7.8 \mathrm{~Hz}, 4 \mathrm{H}), 7.58(\mathrm{t}, J 7.4 \mathrm{~Hz}, 2 \mathrm{H}), 7.47(\mathrm{~d}, J 7.4 \mathrm{~Hz}, 4 \mathrm{H}) .{ }^{13} \mathrm{C} \mathrm{NMR}\left(\mathrm{CDCl}_{3}\right.$, $75 \mathrm{MHz}): \delta 196.63,137.40,133.32,129.93,128.15$.

3-Phenyl-1-(4-(trifluoromethyl)phenyl)prop-2-yn-1-one (2k). ${ }^{28}$ A pale yellow solid (231 $\mathrm{mg}$, $85 \%$ yield). ${ }^{1} \mathrm{H} \mathrm{NMR}\left(\mathrm{CDCl}_{3}, 300 \mathrm{MHz}\right): \delta 8.29(\mathrm{~d}, J 8.1 \mathrm{~Hz}, 2 \mathrm{H}), 7.75(\mathrm{~d}, J 8.4 \mathrm{~Hz}, 2 \mathrm{H})$, 7.69-7.65 (t, 2H), 7.51-7.38 (m, 3H). ${ }^{13} \mathrm{C} \mathrm{NMR}\left(\mathrm{CDCl}_{3}, 75 \mathrm{MHz}\right): \delta 176.51,139.23(\mathrm{q}, J 1.2$ Hz), $134.97(\mathrm{q}, J 32.5 \mathrm{~Hz}), 133.10,131.10,129.67,128.68,125.56$ (q, $J 9.4 \mathrm{~Hz}), 123.45$ (q, $J$ $271.1 \mathrm{~Hz}), 119.51,94.35,86.46$.

1-(4-Methoxyphenyl)-3-phenylprop-2-yn-1-one (2l). ${ }^{28,30}$ A pale yellow solid $(231.5 \mathrm{mg}, 98 \%$ yield). ${ }^{1} \mathrm{H} \mathrm{NMR}\left(\mathrm{CDCl}_{3}, 300 \mathrm{MHz}\right): \delta 8.19(\mathrm{~d}, J 8.7 \mathrm{~Hz}, 2 \mathrm{H}), 7.68-7.65(\mathrm{~m}, 2 \mathrm{H}), 7.50-7.38(\mathrm{~m}$, $3 \mathrm{H}), 6.98(\mathrm{~d}, J 8.7 \mathrm{~Hz}, 2 \mathrm{H}), 3.89(\mathrm{~s}, 3 \mathrm{H}) .{ }^{13} \mathrm{C} \mathrm{NMR}\left(\mathrm{CDCl}_{3}, 75 \mathrm{MHz}\right): \delta 176.62,164.41,132.89$, $131.92,130.55,130.17,128.59,113.81,92.27,86.83,55.54$.

3-Phenyl-1-(thiophen-2-yl)prop-2-yn-1-one (2m). ${ }^{28,30}$ A pale yellow solid (206 $\mathrm{mg}, 97 \%$ yield). ${ }^{1} \mathrm{H} \mathrm{NMR}\left(\mathrm{CDCl}_{3}, 300 \mathrm{MHz}\right): \delta 8.01(\mathrm{~d}, J 3.8 \mathrm{~Hz}, 1 \mathrm{H}), 7.73(\mathrm{~d}, J 4.9 \mathrm{~Hz}, 1 \mathrm{H}), 7.66(\mathrm{~d}, J$ $7.1 \mathrm{~Hz}, 2 \mathrm{H}), 7.49-7.39(\mathrm{~m}, 3 \mathrm{H}), 7.19(\mathrm{t}, J 3.9 \mathrm{~Hz}, 1 \mathrm{H}) .{ }^{13} \mathrm{C} \mathrm{NMR}\left(\mathrm{CDCl}_{3}, 75 \mathrm{MHz}\right): \delta 169.78$, $144.86,135.26,133.00,130.83,128.66,128.32,119.86,91.70,86.41$.

1-(4-Methoxyphenyl)hept-2-yn-1-one (2n). ${ }^{32}$ A slightly yellow liquid (190 mg, 88\% yield). ${ }^{1} \mathrm{H}$ NMR (CDCl $3,300 \mathrm{MHz}): \delta 8.11(\mathrm{~d}, J 9.0 \mathrm{~Hz}, 2 \mathrm{H}), 6.95(\mathrm{~d}, J 9.0 \mathrm{~Hz}, 2 \mathrm{H}), 3.88$ (s, 3H), 2.49 (t, $J$ $7.0 \mathrm{~Hz}, 3 \mathrm{H}), 1.70-1.60(\mathrm{~m}, 2 \mathrm{H}), 1.58-1.44(\mathrm{~m}, 2 \mathrm{H}), 0.96(\mathrm{t}, J 7.4 \mathrm{~Hz}, 3 \mathrm{H}) .{ }^{13} \mathrm{C} \mathrm{NMR}\left(\mathrm{CDCl}_{3}, 75\right.$ $\mathrm{MHz}): \delta 176.96,164.21,131.87,130.28,113.67,95.92,79.57,55.52,29.85,22.05,18.85,13.51$. (E)-1,5-Diphenylpent-1-en-4-yn-3-one (2o). ${ }^{26}$ A slightly yellow solid (209 mg, 90\% yield). ${ }^{1} \mathrm{H}$ NMR $\left(\mathrm{CDCl}_{3}, 300 \mathrm{MHz}\right): \delta 7.92(\mathrm{~d}, J 16.1 \mathrm{~Hz}, 1 \mathrm{H}), 7.67-7.59(\mathrm{~m}, 4 \mathrm{H}), 7.48-7.40(\mathrm{~m}, 6 \mathrm{H}), 6.87$ $(\mathrm{d}, J 16.1 \mathrm{~Hz}, 1 \mathrm{H}) .{ }^{13} \mathrm{C} \mathrm{NMR}\left(\mathrm{CDCl}_{3}, 75 \mathrm{MHz}\right): \delta 178.17,148.31,133.92,132.86,131.12$, $130.57,129.00,128.63,128.59,128.41,120.06,91.49,86.49$.

Propiophenone (2p). ${ }^{30}$ A colorless oil (109 mg, 81\% yield). ${ }^{1} \mathrm{H}$ NMR $\left(\mathrm{CDCl}_{3}, 300 \mathrm{MHz}\right): \delta 7.97$ $(\mathrm{d}, J 7.8 \mathrm{~Hz}, 4 \mathrm{H}), 7.56(\mathrm{t}, J 7.3 \mathrm{~Hz}, 2 \mathrm{H}), 7.46(\mathrm{~d}, J 7.4 \mathrm{~Hz}, 4 \mathrm{H}), 3.01(\mathrm{q}, J 7.2 \mathrm{~Hz}, 2 \mathrm{H}), 1.23(\mathrm{t}, J$ $7.2 \mathrm{~Hz}, 3 \mathrm{H}) .{ }^{13} \mathrm{C} \mathrm{NMR}\left(\mathrm{CDCl}_{3}, 75 \mathrm{MHz}\right): \delta 200.81,136.82,132.83,128.49,127.90,31.72,8.17$. Cyclohexanone (2q). ${ }^{30}$ A colorless oil (> 99\% yield). The yield was determined by ${ }^{1} \mathrm{H}$ NMR from the extraction of the reaction mixture. ${ }^{1} \mathrm{H} \mathrm{NMR}\left(\mathrm{CDCl}_{3}, 300 \mathrm{MHz}\right): \delta 2.32(\mathrm{t}, \mathrm{J} 6.6 \mathrm{~Hz}$, $2 \mathrm{H}), 1.90-1.80(\mathrm{~m}, 4 \mathrm{H}), 1.75-1.67(\mathrm{~m}, 2 \mathrm{H})$.

3-Phenylpropyl 3-phenylpropanoate (2r). ${ }^{31}$ A colorless oil (196 mg, 73\% yield). ${ }^{1} \mathrm{H}$ NMR $\left(\mathrm{CDCl}_{3}, 300 \mathrm{MHz}\right): \delta 7.35-7.28(\mathrm{~m}, 4 \mathrm{H}), 7.26-7.16(\mathrm{~m}, 6 \mathrm{H}), 4.12(\mathrm{t}, J 6.5 \mathrm{~Hz}, 2 \mathrm{H}), 2.98(\mathrm{t}, J 7.8$ $\mathrm{Hz}, 2 \mathrm{H}), 2.66(\mathrm{t}, J 7.7 \mathrm{~Hz}, 4 \mathrm{H}), 2.01-1.90(\mathrm{~m}, 2 \mathrm{H}) .{ }^{13} \mathrm{C} \mathrm{NMR}\left(\mathrm{CDCl}_{3}, 75 \mathrm{MHz}\right): \delta 172.95$, $141.17,140.50,128.50,128.42,128.39$, 128.29, 126.27, 125.99, 63.80, 35.86, 32.12, 30.96, 30.16 .

2-Benzamidoethyl 2-benzamidoacetate (2s). A white amorphous solid (111 mg, 68\% yield). ${ }^{1} \mathrm{H}$ NMR (CD $\left.{ }_{3} \mathrm{OD}, 300 \mathrm{MHz}\right): \delta 7.88-7.76(\mathrm{~m}, 4 \mathrm{H}), 7.56-7.47(\mathrm{~m}, 2 \mathrm{H}), 7.46-7.38(\mathrm{~m}, 4 \mathrm{H}), 4.34(\mathrm{t}$, 
$J 5.4 \mathrm{~Hz}, 2 \mathrm{H}), 4.14(\mathrm{~s}, 2 \mathrm{H}), 3.66(\mathrm{t}, J 5.4 \mathrm{~Hz}, 2 \mathrm{H}) \cdot{ }^{13} \mathrm{C} \mathrm{NMR}\left(\mathrm{CD}_{3} \mathrm{OD}, 75 \mathrm{MHz}\right): \delta 171.37$, $170.51,170.45,135.38,134.79,132.95,132.69$, 129.57, 129.51, 128.37, 128.29, 64.66, 42.62, 40.00. HRMS (ESI) calcd for $\mathrm{C}_{18} \mathrm{H}_{18} \mathrm{~N}_{2} \mathrm{NaO}_{4}\left(\mathrm{M}^{+}+\mathrm{Na}\right)$ : 349.1159; found: 349.1160 .

Cyclohexylmethyl cyclohexanecarboxylate (2t). ${ }^{31}$ A colorless oil (194 mg, 90\% yield), which was a mixture containing $\mathbf{2 t}$ and tert-butyl cyclohexanecarboxylate (2t') according to the ${ }^{1} \mathrm{H}$ NMR spectrum. The molar ratio of $\mathbf{2 t}$ to $\mathbf{2 t}$ ' was approximately 78:22. $\mathbf{2 t}$ (70\% yield). ${ }^{1} \mathrm{H}$ NMR $\left(\mathrm{CDCl}_{3}, 300 \mathrm{MHz}\right): \delta 3.84(\mathrm{~d}, J 6.4 \mathrm{~Hz}, 2 \mathrm{H}), 2.27$ (tt, $\left.J 3.6,11.2 \mathrm{~Hz}, 1 \mathrm{H}\right), 1.92-1.10(\mathrm{~m}, 19 \mathrm{H})$, 1.00-0.86 (m, 2H). ${ }^{13} \mathrm{C} \mathrm{NMR}\left(\mathrm{CDCl}_{3}, 75 \mathrm{MHz}\right): \delta 176.19,69.21,43.27,37.10,29.60,29.02$, 26.32, 25.78, 25.64, 25.43.

2,2-Diphenethoxy-1-phenylethanone (2u). Light yellow oil (50.5 mg, $42 \%$ yield). ${ }^{1} \mathrm{H}$ NMR $\left(\mathrm{CDCl}_{3}, 300 \mathrm{MHz}\right): \delta 8.01(\mathrm{~d}, J 7.6 \mathrm{~Hz}, 2 \mathrm{H}), 7.54(\mathrm{~d}, J 7.2 \mathrm{~Hz}, 1 \mathrm{H}), 7.38(\mathrm{t}, J 7.4 \mathrm{~Hz}, 2 \mathrm{H})$, 7.28-7.09 (m, 10H), 5.24 (s, 1H), 3.88-3.67 (m, 4H), $2.87(\mathrm{t}, J 6.8 \mathrm{~Hz}, 4 \mathrm{H}) .{ }^{13} \mathrm{C} \mathrm{NMR}\left(\mathrm{CDCl}_{3}\right.$, $75 \mathrm{MHz}): \delta$ 193.62, 138.38, 133.62, 133.43, 129.69, 128.95, 128.31, 128.28, 126.30, 102.49, 68.37, 36.16. HRMS (ESI) calcd for $\mathrm{C}_{24} \mathrm{H}_{24} \mathrm{NaO}_{3}\left(\mathrm{M}^{+}+\mathrm{Na}\right)$ : 383.1618; found: 383.1617 .

\section{Acknowledgements}

The authors thank the financial support from the National Natural Science Foundation of China (No. 20971105) and the Fundamental Research Funds for the Central Universities (XDJK2012B011).

\section{References}

1. Wu, X.-F.; Neumann, H.; Beller, M. Chem. Soc. Rev. 2011, 40, 4986-5009. http://dx.doi.org/10.1039/c1cs15109f

2. Larock, R. C. Comprehensive Organic Transformations, A Guide to Functional Group Preparations, 2nd Ed., Wiley-VCH: New York, 1999.

3. Küpper, F.C.; Feiters, M.C.; Olofsson, B.; Kaiho, T.; Yanagida, S.; Zimmermann, M.B.;

Carpenter, L.J.; Luther, G.W. $3^{\text {rd }}$; Lu, Z.; Jonsson, M.; Kloo, L. Angew. Chem. Int. Ed. 2011, 50, 11598-11620.

http://dx.doi.org/10.1002/anie.201100028

4. Togo, H.; Iida, S. Synlett 2006, 2159-2175

http://dx.doi.org/10.1055/s-2006-950405

5. Stavber, S.; Jereb, M.; Zupan, M. Synthesis 2008, 1487-1513.

http://dx.doi.org/10.1055/s-2008-1067037

6. Parvatkar, P. T.; Parameswaran, P. S.; Tilve, S. G. Chem. Eur. J. 2012, 18, 5460-5489. http://dx.doi.org/10.1002/chem.201100324

7. Mphahlele, M. J. Molecules 2009, 14, 5308-5322. 
http://dx.doi.org/10.3390/molecules14125308

8. Ali, S.; Zhu, H.-T.; Xia, X.-F.; Ji, K.-G.; Yang, Y.-F.; Song, X.-R.; Liang, Y.-M. Org. Lett. 2011, 13, 2598-2601. http://dx.doi.org/10.1021/ol2007154

9. Zhu, Y.-p.; Liu, M.-c.; Jia, F.-c.; Yuan, J.-j.; Gao, Q.-h.; Liang, M.; Wu, A.-x. Org. Lett. 2012, 14, 3392-3395. http://dx.doi.org/10.1021/ol301366p

10. Mori, N.; Togo, H. Tetrahedron 2005, 61, 5915-5925. http://dx.doi.org/10.1016/j.tet.2005.03.097

11. Ohmura, R.; Takahata, M.; Togo, H. Tetrahedron Lett. 2010, 51, 4378-4381. http://dx.doi.org/10.1016/j.tetlet.2010.06.051

12. Iida, S.; Togo, H. Tetrahedron 2007, 63, 8274-8281. http://dx.doi.org/10.1016/j.tet.2007.05.106

13. Iida, S.; Togo, H. Tetrahedron 2007, 63, 1474-1480. http://dx.doi.org/10.1016/j.tet.2006.11.077

14. Itoh, A.; Kodama, T.; Masaki, Y. Chem. Lett. 2001, 30, 686-687. http://dx.doi.org/10.1246/cl.2001.686

15. Miller, R. A.; Hoerrner, R. S. Org. Lett. 2003, 5, 285-287. http://dx.doi.org/10.1021/o10272444

16. Gogoi, P.; Sarmah, G. K.; Konwar, D. J. Org. Chem. 2004, 69, 5153-5154. http://dx.doi.org/10.1021/jo0494984

17. Gogoi, P.; Konwar, D. Org. Biomol. Chem. 2005, 3, 3473-3475. http://dx.doi.org/10.1039/b509527a

18. Lee, S. B.; Lee, J. C. Bull. Korean Chem. Soc. 2009, 30, 3107-3108. http://dx.doi.org/10.5012/bkcs.2009.30.12.3107

19. Milazzo, G.; Caroli, S.; Sharma, V. K. Tables of Standard Electrode Potentials, Wiley, Chichester, 1978.

20. Montoro, R.; Wirth, T. Org. Lett. 2003, 5, 4729-4731. http://dx.doi.org/10.1021/o10359012

21. Tanner, D. D.; Gidley, G. C.; Das, N.; Rowe, J. E.; Potter, A. J. Am. Chem. Soc. 1984, 106, 5261-5267. http://dx.doi.org/10.1021/ja00330a038

22. Akhtar, M.; Barton, D. H. R. J. Am. Chem. Soc. 1964, 86, 1528-1536. http://dx.doi.org/10.1021/ja01062a016

23. Tishchenko, V. J. Russ. Phys. Chem. Soc. 1906, 38, 355-418.

24. Luo, Q.-L.; Lv, L.; Li, Y.; Tan, J.-P.; Nan, W.; Hui, Q. Eur. J. Org. Chem. 2011, 6916-6922. http://dx.doi.org/10.1002/ejoc.201101030

25. Heasley, V. L.; Berry, B. R.; Holmes, S. L.; Holstein, L. S. III; Milhoan, K. A.; Sauerbrey, A. M.; Teegarden, B. R.; Shellhamer, D. F. J. Org. Chem. 1988, 53, 198-201. http://dx.doi.org/10.1021/jo00236a043 
26. Alonso, D. A.; Nájera, C.; Pacheco, M. C. J. Org. Chem. 2004, 69, 1615-1619. http://dx.doi.org/10.1021/jo035761+

27. Santra, S.; Dhara, K.; Ranjan, P.; Bera, P.; Dash, J.; Mandal, S. K. Green Chem. 2011, 13, $3238-3247$. http://dx.doi.org/10.1039/c1gc15869d

28. Park, A.; Park, K.; Kim, Y.; Lee, S. Org. Lett. 2011, 13, 944-947. http://dx.doi.org/10.1021/ol102993y

29. Han, C.; Yu, M.; Sun, W.; Yao, X. Synlett 2011, 2363-2368. http://dx.doi.org/10.1055/s-0030-1261227

30. AIST: Integrated Spectral Database System of Organic Compounds. (Data were obtained from the National Institute of Advanced Industrial Science and Technology (Japan)) http://sdbs.db.aist.go.jp/sdbs/cgi-bin/direct_frame_top.cgi

31. Kim, S.; Bae, S. W.; Lee, J. S.; Park, J. Tetrahedron 2009, 65, 1461-1466. http://dx.doi.org/10.1016/j.tet.2008.12.005

32. Friis, D.; Taaning, R. H.; Lindhardt, A. T.; Skrydstrup, T. J. Am. Chem. Soc. 2011, 133, 18114-18117.

http://dx.doi.org/10.1021/ja208652n 